COGNitive STUdies | ÉTUdes COGNitives, 10

VIOLETTA KOSESKA-TOSZEWA ${ }^{1}$ ANTONI MAZURKIEWICZ ${ }^{2}$

${ }^{1}$ Institute of Slavic Studies, Polish Academy of Sciences, Poland

${ }^{2}$ Institute of Computer Science, Polish Academy of Sciences, Poland

\title{
CONSTRUCTING CATALOGUE OF TEMPORAL SITUATIONS ${ }^{1}$
}

\begin{abstract}
The paper is aiming to create a common basis for description, comparing, and analysis natural languages. As a subject of comparison we have chosen temporal structures of some languages. For such a choice there exists a perfect tool, describing basic temporal phenomena, namely an ordering of states and events in time, certainty and uncertainty, independency of histories of separate objects, necessity and possibility. This tool is supported by the Petri nets formalism (Petri 1962), which seems to be well suited for expressing the above mentioned phenomena. Petri nets are built form three primitive notions: of states, of events that begin or end the states, and so-called flow relation indicating succession of states and events. This simple constituents give rise to many possibilities of representing temporal phenomena; it turns out that such representations are sufficient for many (clearly, not necessarily all) temporal situations appearing in natural languages (Koseska-Toszewa 2007, Reichenbach 1944).

In description formalisms used till now there is no possibility of expressing such reality phenomena as temporal dependencies in compound statement, or combination of temporality and modality. Moreover, using these formalisms one cannot distinguish between two different sources of uncertainty of the speaker while describing the reality: one, due to the lack of knowledge of the speaker what is going on in outside world, the second, due to objective impossibility of foreseen ways in which some conflict situations will be (or already have been) resolved. Petri net formalism seems to be perfectly suited for such differentiations.

There are two main description principles that encompassed this paper. First, that assigns meaning to names of grammatical structures in different languages may lead to misunderstanding. Two grammatical structures with apparently close names may describe different reality. Additionally, some grammatical terms used in one language may be absent and not understandable in the other. It leads to assign meanings to situations, rather than to linguistic forms used for their expression. The second principle is
\end{abstract}

\footnotetext{
${ }^{1}$ Work supported by EU FP7 project GA211938 MONDILEX "Conceptual Modelling of Networking of Centres for High-Quality Research in Slavic Lexicography and Their Digital Resources".
} 
limit the discussed issues to such a piece of reality that can be possible for precise description. The third is to avoid introducing such information to the described reality that is not explicitly mentioned by linguistic means. The authors try to following these principles in the present paper.

The paper is organized as follows. First, some samples of situations related to present tense are given together with examples of their expressions in four languages: English, (as a reference language) and three Slavic languages, representing South slavonic languages (Bulgarian), West slavonic languages (Polish), and East slavonic languages (Russian). Within the same framework the next parts of the paper are constructed, supplying samples of using Past tenses and, finally, future tenses and modalities.

The formal tools for description purposes are introduced stepwise, according to needs caused be the described reality. There are mainly Petri nets, equipped additionally with inscriptions or labeling in order to keep proper assignations of description units to described objects.

Keywords: Sentences, tenses, states, events, time flow, Petri nets, modality

\section{Outline of the approach}

\subsection{Formalized situation description}

The main difficulty of explanation or comparison of different verbal forms is the necessity of defining the situation expressed by the described forms. In this paper we propose to define a number of so-called situation functions that maps chosen verbs into situations corresponding to the used verbal form. There can be a number of various methods of situation describing; according to our previous papers we use the Petri net formalism describing situations in many aspects, both temporal as modal (Petri 1962). In general, the syntax of situation function is:

$$
\text { Function_name }\left(x_{1}, x_{2}, \ldots, x_{n} ; p_{1}, p_{2}, \ldots, p_{k}\right)=\text { Situation }
$$

where Function_name is the name of a verbal form, $x_{1}, x_{2}, \ldots, x_{n}$ are verb arguments, $p_{1}, p_{2}, \ldots, p_{k}$ are some auxiliary information, if necessary (as e.g. point of reference, passive or active voice indications, or other subjects of verbs), and Situation is the situation, to which the verbs $x_{1}, x_{2}, \ldots, x_{n}$ and data $p_{1}, p_{2}, \ldots, p_{k}$ are referring to. This reference is made by the verbal form specific for the chosen function. Schemes of actions, corresponding to verbs of languages, can consist of a number of states and/or events mutually connected.

It is worthwhile to make clear the intention for introducing situation descriptions. Such descriptions are not thought as a material for machine processing, but as a mean for understanding the meaning of sentences referring to chosen situations. To process sentences (not situations) there is a need of formal and precise meaning conveyed by them. Introducing a catalogue of situations, one can assign chosen entries of such catalogue to some (parts of) sentences subjected for processing and then create a formal basis for comparison them in different languages. It should be stressed that the sentences are subjected to processing, not positions in such catalogue. In order to make a progress in machine translation there is no escape of 
dealing with the meaning of sentences. The intention of this paper (and preceding ones) is to offer (at least partial) formal means to cope with this issue.

There are several possibilities of defining meaning of temporal properties of sentences. Here, we chose net description, since nets can grasp (a) difference between events and states; (b) the temporal sequencing, not only linear but also partial; (c) coexistence or exclusion of some parts of situations; (d) choice of different possibilities, accomplished or not; (e) some aspects of modality; (f) language independency. We are aware of existence of other possibilities of situation description and of shortcomings or incompleteness of our approach; however, we are convinced that our proposal is a step in proper direction. Clearly, the introduced formalism can be subjected to further completions and improvements; for the time being, we limit ourselves to Petri nets formalism with some net elements marked, if necessary.

\subsection{Situation functions}

Situation descriptions by nets consist of net schemes (using circles for representing states, boxes for representing events, and arrows for representing sequencing). The state of speech is marked with a dot. Some net elements can be marked with symbols of variables that are provided for representing actual actions, states, or events while the function is used. A number of net elements can be marked with the same variable, if this variable refers to all of them; on the other hand, some net elements can be left unmarked, if they serve for a proper sequencing and the scheme building only. In what follows some examples of situation functions usage is presented, for situations that are used most frequently.

Recall here the basic elements of the description formalism od temporal situations suited for the linguistic purposes. These elements, following (Petri 1962) are: (1) states, representing physical or mental phenomena that are extended in time, (2) events, which represent some changes of states and taking no time, and (3) the flow (ordering) relation, binding states with events and indicating their mutual succession. It turns out that the three elements mentioned above are sufficient for expressing many of every-day situations in a language-independent way, as indicated in (Koseska, Mazurkiewicz 1988). In fact, the language of states, events, and flow is a sort of an artificial language, serving as an intermediate (go-between) language, also known as "tertium comparationis". Call it the Petri net language, or the net language for short. The reader can consult some source texts on Petri Nets, eg. (Reisig 1985), or some earlier papers of the present authors, as e.g. (KoseskaToszewa 2007), (Mazurkiewicz 2008), to find the detailed description of the net formalism.

\subsection{Formalism of nets}

For the purpose of the present paper it suffices to recall the following facts.

Petri nets as used here are built of three basic elements: events (symbolized by boxes), states (symbolized by circles) and flow relation (symbolized by arrows). Any finite structure consisting of these elements, with some of them joint by flow relation in such a way that it connects a state with an event, or an event with a 
state (neither two states nor two events are directly connected by the flow). An alternating sequence of states and events connected directly by the flow relation is called a path through the net and indicates the sequence in which these elements appear in time. Any two elements of the same path are ordered in time: either one of them precedes the other, or the other way round. Nets with places from which there is only one arrow leaving it or pointing to it we call deterministic. Example of a deterministic net is given in Fig.1.

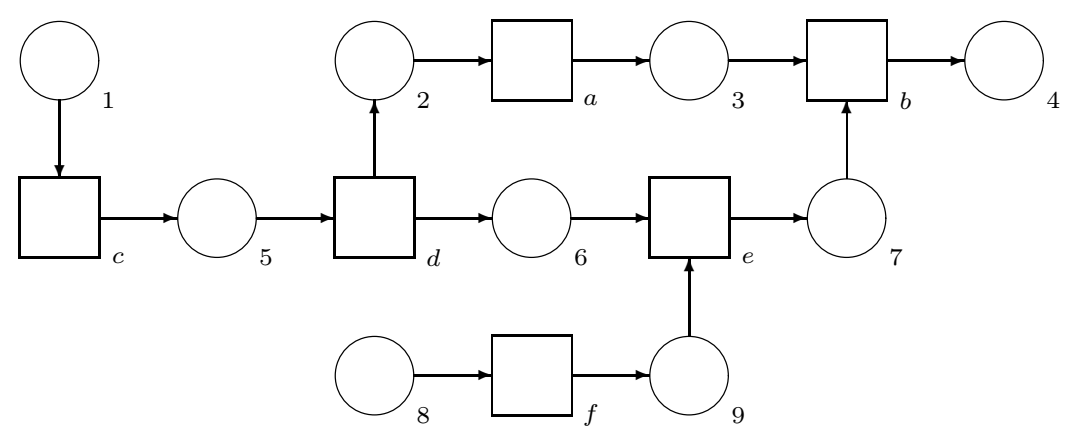

Fig. 1. Deterministic net

In a deterministic net any two elements not lying on the same path are independent of each other. Thus, elements of any two separate paths starting or terminating with a common event are independent or, in other words, are coexistent. E.g. in the picture above state 6 and state 3 are coexistent, but state 5 precedes state 3 and state 7 follows state 8 . Similarly, events $c$ is independent of $a$, but it follows event $d$. Event $c$ can only happens in state 2 or in state 3 , but its occurrence precedes state 4 .

To bind elements of nets with elements of situations we use the following conventions. States are marked with capital letters, in contrast to events that are marked with small ones. However, if an event is terminating (or initiating) a state and this fact is stressed in the sentence, it is marked with the same symbol as the state. Similarly, if a state is an effect (or a result) of an event and this fact is stressed in a sentence, then it is marked with the same symbol as the event. An example of such a marking is given in Fig. 2. Place marked with • denotes the state of utterance. In this figure we have:

$y$ event closing the preceding state

$x$ event resulting with the following state

$P$ State initiated by the preceding event

$R$ State terminated by the following event

Some elements (events or states) of nets that are used in descriptions are introduced only for a proper ordering the remaining ones, i.e. for sequencing or establishing independency among net elements; they do not support any meaning assigned to elements of sentences being represented. 


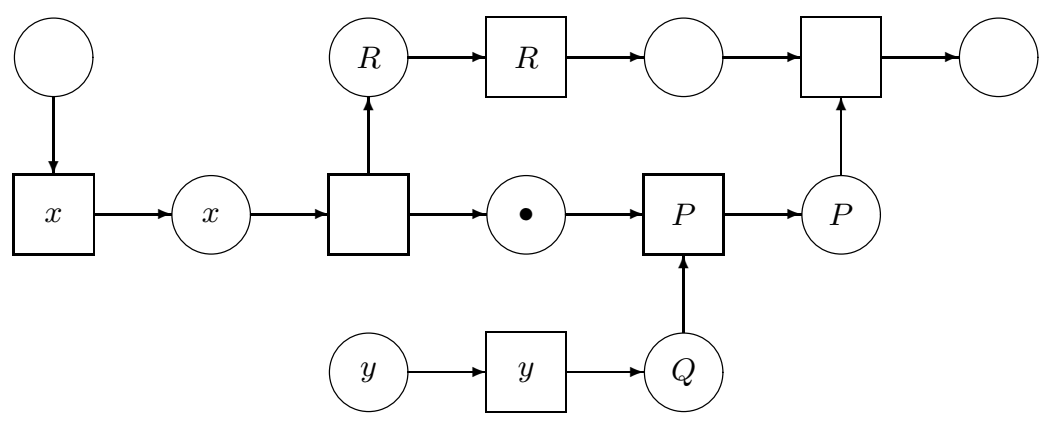

Fig. 2. Marked net conventions

In some cases we want to have an indefinite number of net elements for describing a situation. In such a case we use cycles instead of sequences of net elements; a cycle represent all possible paths that can be contained in the cycle. In the sequel we use such a cycle in one case only, to represent a repetition of some states and events. Namely, we use the scheme in Fig. 3 as a tool for representation of an arbitrary sequence of alternating states $P, Q$ separated by events $b, d$, starting with state $P$ and ending with state $Q$.

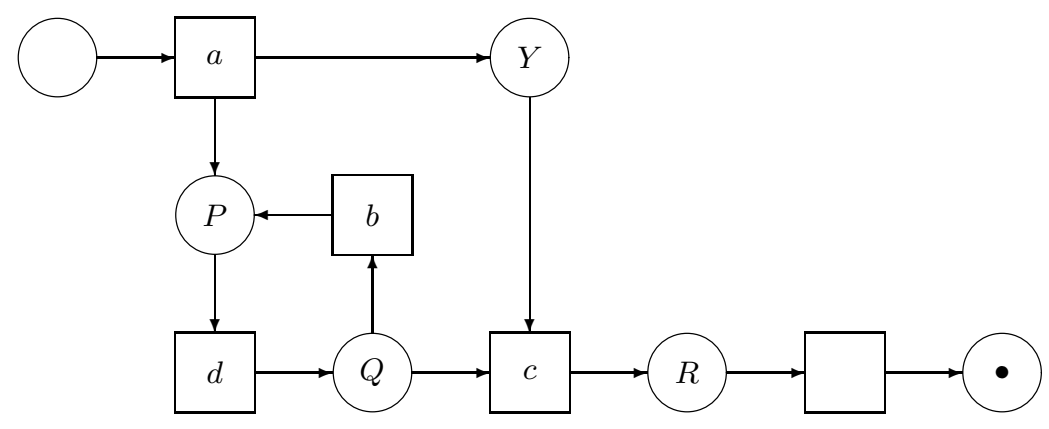

Fig. 3. Cyclic net

So-called "unfolding" of presented cyclic net is given in Fig. 4

$$
(a, P, d, Q, b, \ldots, P, d, Q, b, P, d, Q, b, \ldots, d, Q, c, R, \ldots)
$$

Events $a$ and $c$ serve for indicating the beginning and ending the repetition. In other words, the following net is an instance of the scheme given above, with indices 1,2,3 and 4 indicate successive instances of events and states being repeated:

In the present paper we argue for (1) creating a catalogue of temporal situations that can be useful for comparison, analyzing, processing, or translating phrases in different languages containing temporal dependencies; (2) distinguishing verbal forms from temporal meaning in different languages. The first aim results from a 


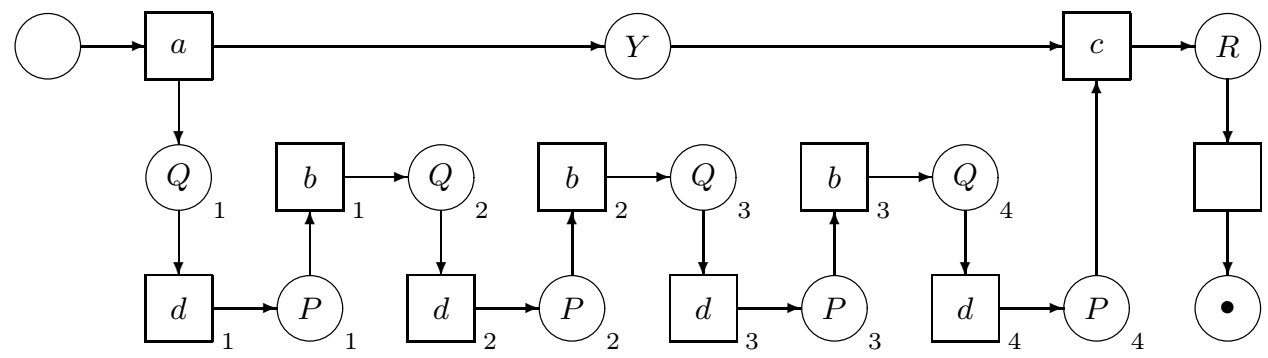

Fig. 4. Unfolding the net in Fig. 3

need of proper understanding temporal statements in various languages; without understanding their proper meaning one is not able to compare them or to create a reliable correspondence between them. The second objective follows from the fact that the same or similar verbal forms in different languages may describe different temporal situations. Therefore we should rely on meaning rather than form while comparison phrases in different languages or trying to make their faithful translation. Some examples of different verbal forms with a similar functionality are given through the paper. In Table 1 a comparison of temporal meanings and corresponding to them verbal forms, discussed in the paper, are given. In Table 2 we list some situation functions together with their situation values.

\section{Past and Present}

A simple example of a situation function is function $\operatorname{Pr}(x)$ corresponding to the present tense. This function takes verb $x$ and returns the situation given in Fig. 5 . The only verb variable occurring in the scheme is $x$; one can substitute for it different concrete verbs. The scheme described the situation with action determined by $x$ is being performed when the speaker is telling about it. Moreover, the beginning and ending of the speaker statement occur while $x$ is holding. It means that during the whole act of utterance the action $x$ (or a state described by it) is holding.

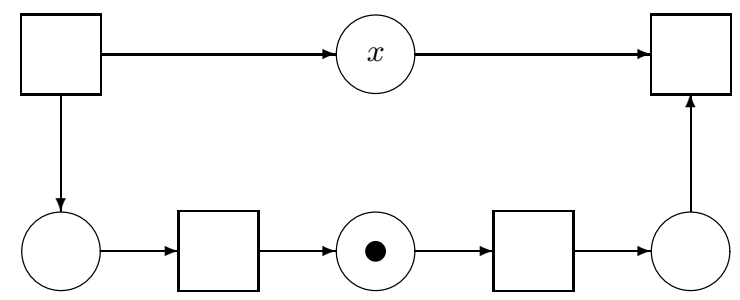

Fig. 5. $\operatorname{Pr}(x)$ 
Linguistic examples of $\operatorname{Pr}(x)$ for $x=$ 'to read' are:

(Eng) He is reading a book (now)

(Bul) Той (точно сега) чете книга

(Pol) On (teraz) czyta ksiażke

(Rus) Он (именно сейчас) читает книгу

\subsection{Past Perfective tense}

The value of $P p(x)$ function (corresponding to Past perfective tense) is the situation where $x$ expresses an activity completed before the state of utterance. In Bulgarian this situation is described by the aorist form of perfective verbs, in Polish and Russian by the praeteritum form of perfective verbs. The situation function $P p(x)$ is presented in Fig. 6 .

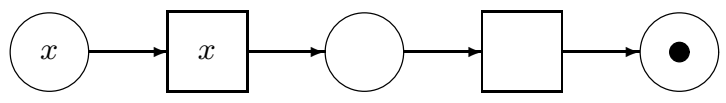

Fig. 6. $P p(x)$

Linguistic examples of $P p(x)$ for $x=$ 'to open' are:

(Bul) Мария вчера отвори вратата

(Eng) Mary opened the door yesterday

(Pol) Maria otworzyła wczoraj te drzwi

(Rus) Мария открыла вчера эту дверь

The result of action $x$ may hold or may not hold at the state of utterance. Observe also that the speaker refers to $x$ together with its termination, i.e. to the perfective version of action $x$.

\subsection{Past Perfective Resultative tense}

Similarly to the Past Perfective tense, the Past Perfective Resultative tense expresses an action terminated before the state of utterance, but now, in contrast to the above mentioned tense, with a result coexistent with the utterance state. In Bulgarian this tense is expressed by the perfectum form of perfective verbs, in Polish and Russian by the praeteritum form of perfective verbs. This tense is corresponding to situation function $\operatorname{Rpp}(x, y)$ defined in Figure 7.

Variable $x$ is used for the verb defining the action in question, $y$ represents its effect. Observe that the state $y$ and the state of utterance are coexistent, as terminated by a common (anonymous) event. Linguistic examples of $R p p(x, y)$ for $x=$ 'to open' and $y=$ 'is open' are: 
(Bul) Мария вече отвори вратата (вратата е отворена)

(Eng) Mary already opened the door (the door is open)

(Pol) Maria już otworzyła te drzwi (drzwi sa otwarte)

(Rus) Мария уже открыла эту дверь (дверь открыта)

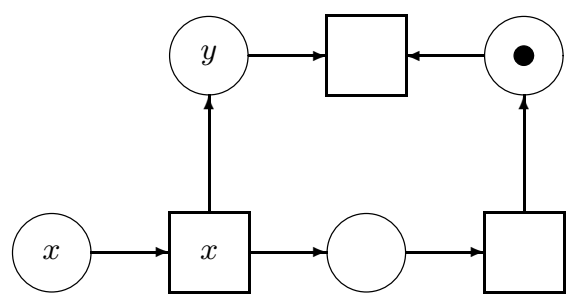

Fig. 7. $R p p(x, y)$

\subsection{Past Imperfective tense}

This tense is used to describe situations similar to those expressed by Past Perfective, but without reference to the moment of the action termination; it may happen that before the state of utterance such a moment will never occur, or at least the speaker is not aware about that. The corresponding situation is the value of function $\operatorname{PImp}(x)$ presented in Figure 8.

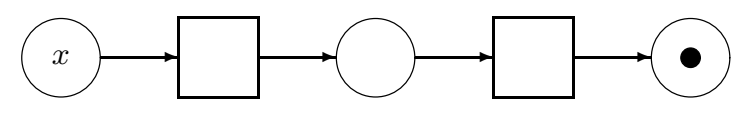

Fig. 8. $P \operatorname{Imp}(x)$

Linguistic examples of such situations are:

(Bul) Мария отваря́ тази врата

(Eng) Mary was opening the door

(Pol) Maria otwierata te drzwi

(Rus) Мария открывала эту дверь

\subsection{Past Imperfective Resultative tense}

The value of $\operatorname{Irp}(x, y)$ for verbs $x$ and $y$ (corresponding to Imperfective Resultative Past tense) is the situation where the action $x$ takes place before the state of 
utterance, but the state $y$ resulting in effect of action $x$ is coexistent with the state of utterance (Figure 9). The speaker does not refer to the completion of action $x$ but, instead, to the result $y$ of this action. In bulgarian this situation is expressed by form Perfectum of imperfective verbs, in Polish and Russian by form Praeteritum of imperfective verbs.

Linguistic examples of $\operatorname{Irp}(x, y)$ for $x=$ 'to be have influenza' ('to write poems') and for $y=$ 'to cough' ('possible to be read') are:

(Bul) Той е боледувал от грип (и сега кашля) На младини Мария е писала стихове (можеш да ги прочетеш)

(Eng) He had influenza (and he is coughing now) Mary was writing poems in her youth (you can read them now)

(Pol) On chorowat na grype ( $i$ teraz kaszle) $W$ młodości Maria pisała wiersze (możesz je przeczytać)

(Rus) Он болел гриппом (у него теперь кашель) В молодости Мария писала стихи (можешь прочитать их)

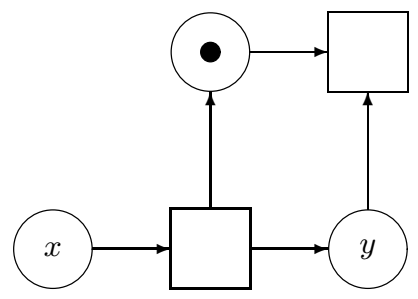

Fig. 9. $\operatorname{Irp}(x, y)$

Here, we limit ourselves to discuss only small part of temporal tenses used in natural languages, namely to present tense and some types of the past tenses. We hope they offer an opportunity of grasping the idea of situation functions that base on formal methods of situation description. In the future we plan to extend the domain of situation functions as well as to enrich their expressive power by introducing new information parameters and by improving their formalism. We propose to construct a catalogue of temporal situations that are used in different languages by means of different linguistic formalisms. Entries to such an catalogue are thought to be (parameterized) names of temporal situations, and values corresponding to them should be descriptions of temporal situations, described as formally and precisely as possible. In the paper temporal situations are presented by the formalism of Petri nets, although any other formalism can be used for this purpose as well. Starting from the meaning of temporal situations rather than from grammatical forms makes possible to compare a wide bunch of languages with different types of temporality formalism (Koseska-Toszewa 2007; Mazurkiewicz 2008; Petri 1962). 
The aim of this section is to present a progress on the work aiming to create a language independent list of basic temporal situations. In this chapter we formulate some rules of the catalogue construction as well as a number of temporal situations expressed in the proposed formalism. These situations are also explained in an informal way and some examples of corresponding phrases expressed in different languages are given. This list is supposed to be a common framework for comparing linguistic forms used for describing the listed situations. As it has been already said (Koseska, Mazurkiewicz 1988) the comparison should me made on the basis of situations rather than grammatical (linguistic) forms.

Table 1. Comparison of temporal meanings and corresponding verbal forms

\begin{tabular}{|c|c|}
\hline Temporal meaning & Verbal form \\
\hline Present & Present tense form (Eng., Bul., Pol., Rus.) \\
\hline Past Perfective & $\begin{array}{c}\text { Past Pefective form (Eng.) } \\
\text { Aorist perfective form (Bulg.) } \\
\text { Praeteritum of perfective verbs (Pol., Rus.) }\end{array}$ \\
\hline Past Perfective Resultative & $\begin{array}{l}\text { Past Perfective form (Eng.) } \\
\text { Perfectum form of perfective verbs (Bulg.) } \\
\text { Praeteritum form of perfective verbs (Pol., Rus.) }\end{array}$ \\
\hline Past Imperfective & $\begin{array}{l}\text { Past continuous (Eng.) } \\
\text { Aorist form of imperfective verbs (Bulg.) } \\
\text { Praeteritum form of imperfective verbs (Pol., Rus.) }\end{array}$ \\
\hline Past Imperfective resultative & $\begin{array}{c}\text { Perfective Continuous (Eng.) } \\
\text { Perfectum of imperfective verbs (Bulg.) } \\
\text { Praeteritum of imperfective verbs (Pol., Rus.) }\end{array}$ \\
\hline
\end{tabular}


Table 2. Sample of situation function entries

\begin{tabular}{|c|c|c|}
\hline Entry & Situation & Meaning \\
\hline $\operatorname{Pr}(x)$ & & Present \\
\hline$P p(x)$ & & Past Perfective \\
\hline$R p p(x, y)$ & & Past Perfective Resultative \\
\hline $\operatorname{PImp}(x)$ & & Past Imperfective \\
\hline $\operatorname{Irp}(x, y)$ & & Past Imperfective Resultative \\
\hline
\end{tabular}

\subsection{Past situations}

In this section we give a formal description of situations placed in the past with respect to the state of speech (the state of utterance). The number of such situations results results from the number of mutual positions of (a) state (or point) of reference, see (Reichenbach 1944), (b) object state (or states), to which the utterance refers, (c) their ordering (or lack of ordering, i.e. the coexistence), (d) possible repetitions of object states and events. The list of situation schemes is certainly not exhaustive; but we hope that it offers a pattern for further extensions. 


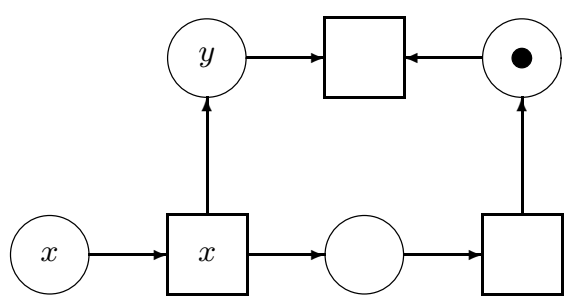

Fig. 10. $R p p(x, y)$

In Bulgarian, event $(v)$ is expressed by aorist form of perfect verbs, while in Polish and Russian by praeteritum form of them. In all four languages state $P$ is expressed by the past participle form.

In Polish and Russian this temporal situation is expressed similarly by praeterital form of perfective verbs. It can also be expressed by a noun with a preposition, in Polish przed, in Russian $\partial o$. However, in Bulgarian the preceding event $p$ is expressed by the pluperfect form of perfective verbs. Even $q$ can be expressed in similar way in Polish and Russian by nouns with prepositions and also by the infinitive form of perfective verbs.

\section{Scheme 1}

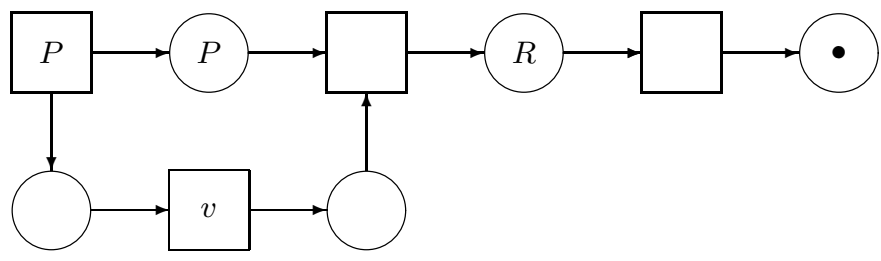

(Eng) He had been drunk $(P)$ when visitors entered $(v)$

$(\mathrm{Bul})$ Когато гостите влязоха $(v)$, той беше вече пиян $(P)$

(Pol) Gdy goście weszli (v), on już był pijany $(P)$

(Rus) Когда гости вошли (v), он уже был пъян (P)

Fig. 11. Past perfective resultative

This temporal situation is precisely expressed in English and Bulgarian by pluperfect form of perfective verbs. In Polish and Russian, additionally, it is supplemented by prepositions with praeterital form of perfective verbs, as zanim, przed, (Pol) перед тем, как (Rus) or similar. In Polish pluperfect form is archaic. 
Scheme 2

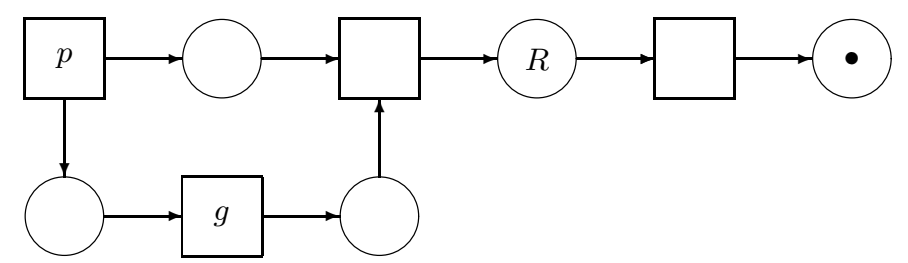

(Eng) He had got drunk (p) before visitors entered $(g)$

(Bul) Tой се бе напил (p), преди $\{$ да дойдат, идването на\} гостите (g)

(Pol) On się upit jeszcze (p) przed przyjściem gości $(g)$

(Rus) Он напился (р) до прихода гостей (g)

Fig. 12. Past before past

Other examples of expressing the temporal situation presented in Fig. 12 are:

(Bul) Той беше дошгл (p), преди тя да дойде (g)

(Eng) He had come here (p) before she did $(g)$

(Pol) On tu $\{$ byt $\}$ przyszedt $(p)$ zanim przyszła ona $(g)$

(Rus) Он пришел (p) перед тем, как пришла она (g)

The difference between Scheme 2 and Scheme 3 consists in changing the position of event $g$ and reference state $R$. Position of the reference state in Scheme 3 indicates its coexistence with state $p$; it means that after $g$ has happened, state $P$ can still be holding, according to the story told by a speaker at place $\bullet$ (the state of utterance).

Scheme 4 presented in Fig. 14 is similar to Scheme 2, but with a state $(P)$ instead of event $(p)$ in its temporal structure.

\subsection{Repetitive situations}

Schemes discussed in this section differ from the ones given above. Namely, Scheme 4 given below contains two states ( 1 and 2 ) that can be started or terminated with two different events each, henceforth (according to the net properties) excluding each other. State 1 can be initiated by event $a$ beginning the cycle, or by $b$ repeating the cycle. State 2 can be terminated with event $c$, continuing the cycle, or with $b$, closing the repetitions of the cycle. The number of repetitions is undefined, and is left to the "decision" made at state 2 : to leave repetitions by event $b$, or to return to them by event $c$. Therefore, Scheme 4 describes a class of situations rather than a single one; which one of them is actually expressed is irrelevant from the speaker's point of view.

In Bulgarian, the temporal situation (see fig. 15) is expressed by the imperfect form of imperfective verbs. In Polish and Russian it is expressed by the praeterital form of imperfective verbs.

According to the general rules of net understanding, there is a number of histories consistent with such a scheme, in each history all states terminate or start 


\section{Scheme 3}

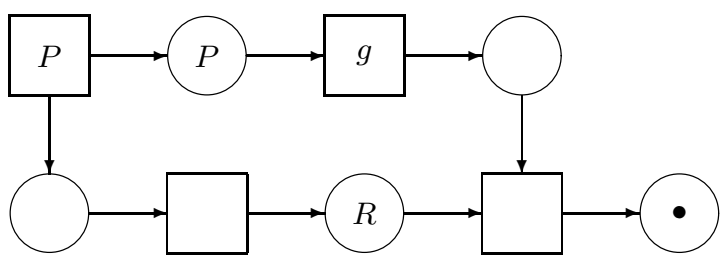

(Eng) He had been drunk $(P)$ before visitors entered $(g)$

(Bul) Той стана $(P)$ пиян преди да дойдат гостите $(g)$

$(\mathrm{Pol})$ On stał się $(P)$ pijany już przed przyjściem gości $(g)$

(Rus) Он захмелел еще $(P)$ до прихода гостей (g)

Fig. 13. Past before past perfective

\section{Scheme 4}

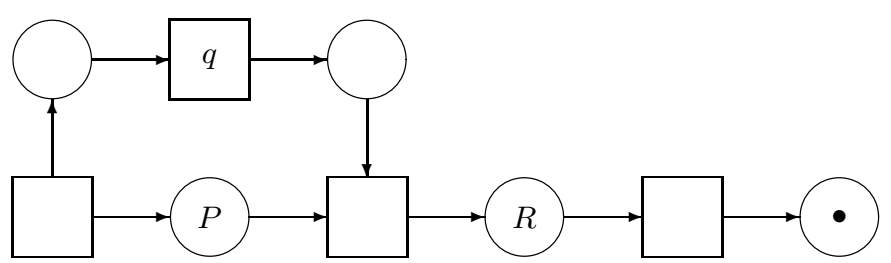

(Bul) Той вече беше дошб́л (P) когато тя дойде(q)

(Eng) When she came $(q)$ he $\{$ was, has been $\}$ already here $(P)$

(Pol) On już tu był (P), gdy ona przyszła (q)

(Rus) Он уже бъл (P), когда она пришла $(q)$

Fig. 14. Past before past

with only one event. In this way the above scheme describes several possibilities of the history course; therefore, it describes a situation where state $p$ is repeatedly renewed, starting and ceasing to exist in an alternating way. All these actions take place during state $Y$ is holding; state $Y$ and all instances of states and events in the cycle are coexistent; in particular, state $Y$ is coexistent with all occurrences of event $p$.

Next schemes show various versions of expressing repeating situation in dependence on their position with respect to the reference state (which is always situated in the past). Symbol $x$ denotes the action (state) the situation is referring to. Scheme 7 describes repeating situation coexistent with the reference state.

It is worth to notice that in the above diagram states • (of utterance), $R$ (of reference), and repetitive structure containing event $x$ are independent, so to speak, coexistent. Therefore, all states and events of this repetitive structure are coexistent 


\section{Scheme 5}

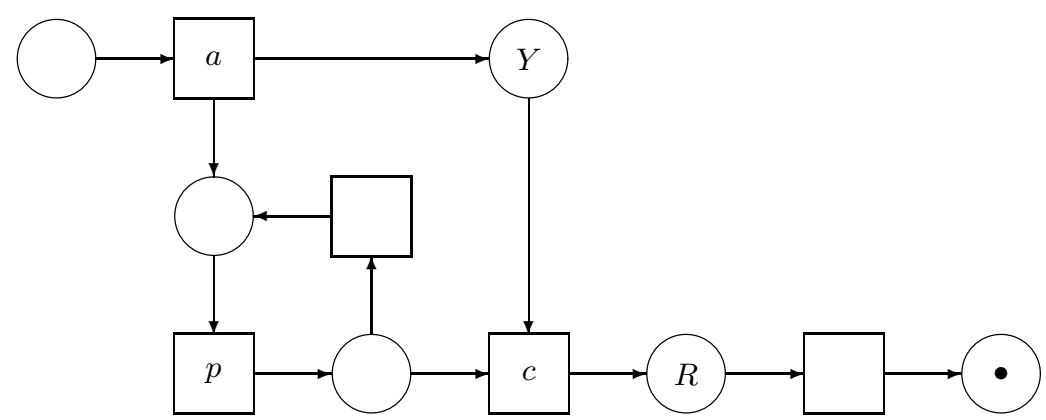

(Bul) Миналата година $(Y)\{$ понякога, често, рядко $\}$ той я посещаваше $(p)$ (Eng) Last year $(Y)$ he was visiting her $(p)$ \{occasionally, frequently, sporadically\} $(\mathrm{Pol}) W$ zesztym roku $(Y)$ on $\{c z a s e m$, często, rzadko\} ja odwiedzat $(p)$ (Rus) B прошлом году (Y) он \{иногда, часто, редко $\}$ ее посещал ( $p$ )

Fig. 15. Repetitive situation

\section{Scheme 6}

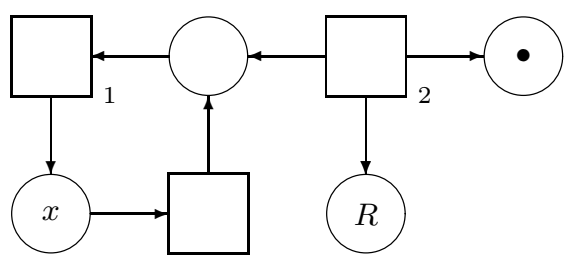

Fig. 16. Repetitive at present

with both reference and utterance states. Examples of expressing this situation are as follows:

(Bul) Тя сега \{от време на време\} сяда при прозореца

(Eng) Nowadays, she is sitting by the window from time to time

(Pol) Ona teraz od czasu do czasu siaduje przy oknie

(Rus) Сейчас \{время от времени, часто\} она садится у окна

In all languages mentioned above but Polish the repetitive character of the action in question is expressed by supplementing it with adverb from time to time (Eng), от време на време (Bul), время от времени (Rus). In Polish verb siaduje indicates explicitly the repeatability of the action, derived from imperfective verb siadać. 


\section{Scheme 7}

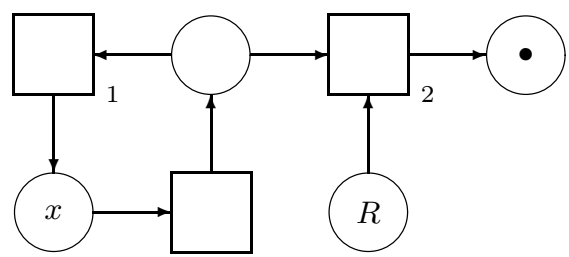

(Bul) Тя от време на време сядаше при прозореца

(Eng) She used to sit by the window from time to time

(Pol) Od czasu do czasu ona siadywała przy oknie

(Rus) Время от времени она садилась у окна

Fig. 17. Repetitive in the past

Scheme 7 given in Fig. 17 expresses the same situation as Scheme 6, but shifted to the past with respect to the reference state. In this diagram state $R$ of reference as well as the whole diagram of repeating states and events are in the past of the state of utterance •. However, similarly to the scheme 6 , state of reference $R$ is coexistent with the whole repeating structure — between them there is no temporal dependency whatsoever. In Polish and Russian the above temporal situation is expressed by praeterital form of imperfective verbs, while in Bulgarian it is expressed by the imperfect form of imperfective verbs. Scheme 8 presented in Fig. 18 is quoted to indicate a possibility of use the reference as an event rather than as a state; that is, it is then a "point of reference" rather than a "reference state".

In Polish and Russian this temporal situation is expressed praeterital form of imperfective verbs. In Bulgarian it is expressed by imperfect form of imperfective verbs.

In the present section we deal with net representation of temporal situations referring to the past. Some basic situations have been listed and explained using net formalism. With a single exception of repeating occurrences of situation elements there were no need to represent modalities such as different possibilities of the history courses, or uncertainty of some states 0r events occurrences in the described situations. This issue is left for the next section.

Above, we have presented a continuation of the work on creating a catalogue of temporal situations based on Petri nets theory. The list of situations presented in this paper is certainly not exhaustive; one can find a number of situations worth of listing and analyzing for the linguistic purposes. However, this list give a guidance for the next discussion on situation presentations and is open for a further augmenting and completion. In the next section we intend to create a similar list for situations related to the future and to various aspects of modality. 
Scheme 8

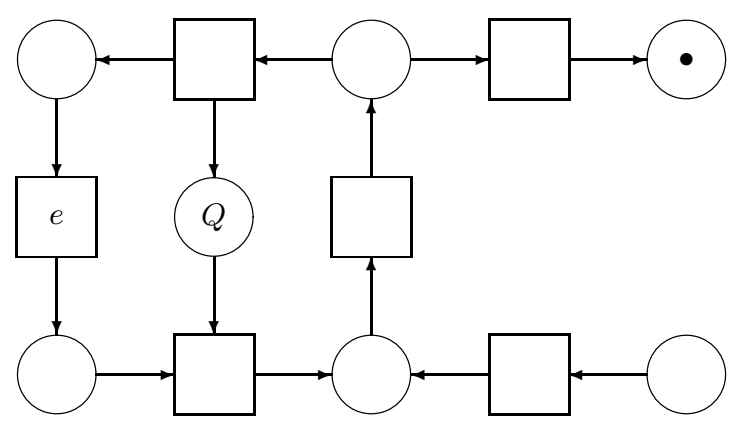

(Bul) Той винаги в такгв един момент (е) я ненавиждаше (Q)

(Eng) He was hating her $(Q)$ at any such a moment (e)

(Pol) W każdej takiej chwili on ja nienawidzit (e)

(Rus) Он всегда в такой момент (е) ее ненавидел (Q)

Fig. 18. Repetitive situation in the past 
Table 3. List of used situation functions

\begin{tabular}{|c|c|c|}
\hline Scheme & Situation & Temporal meaning \\
\hline Scheme 1 & & $\begin{array}{l}\text { Past perfective resultative, with state as the } \\
\text { object }\end{array}$ \\
\hline Scheme 2 & & Past before past, with event as object \\
\hline Scheme 3 & & $\begin{array}{l}\text { Past perfective, with object coexistent with } \\
\text { reference }\end{array}$ \\
\hline Scheme 4 & & Past before past, with state as object \\
\hline Scheme 5 & & $\begin{array}{l}\text { Past repetitive imperfective, with event as } \\
\text { object }\end{array}$ \\
\hline Scheme 6 & & Repetitive at present \\
\hline Scheme 7 & & Repetitive in the past \\
\hline Scheme 8 & & Repetitive situation in the past \\
\hline
\end{tabular}




\section{Future and Possibility}

A single net can represent more than one history; a history is a possible course of actions and states described by the supporting net. Transitions (actions) and places (states) can occur within a history several times, if they are contained in a cycle of the net; therefore, we should speak about element occurrences rather than about elements themselves.

A history supported by a net has the following properties. Firstly, it contains the state of utterance. Secondly, if it contains an event, it contains also all its preconditions and all its postconditions, as indicated by the supporting net. Thirdly, if a history contains a state, then it contains at most one event initiating it and at most one event terminating it, if such events do exist.

A history is complete, if it cannot be extended by adding new objects. A complete history of a net containing cycles that can be infinite; in such cases we frequently use a partial history.

Below we listed net schemes of chosen real situations related to the future and to different aspects of possibilities.

\section{Scheme 9}

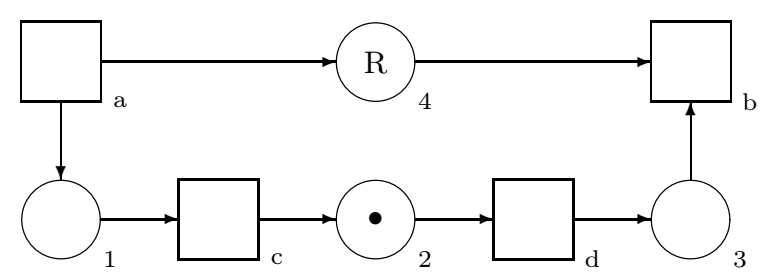

(Bul) Иван сега чете вестник

(Eng) Now, John is reading a newspaper

(Pol) Jan teraz czyta gazete

(Rus) Иван сейчас читает газету

(2) Teraz Now

(4) Czytanie Reading

Fig. 19. Present 
Scheme 10

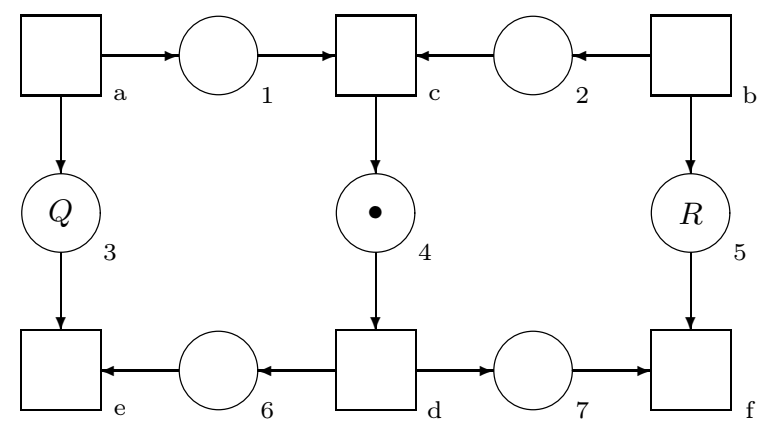

(Bul) Иван е болен и лежи в болнищата (Eng) John is ill and he is in hospital (Pol) Jan leży chory i jest w szpitalu (Rus) Иван болен и лежит в больнище

\begin{tabular}{|ll|}
\hline (3) jest chory & is ill \\
(5) jest w szpitalu & is in hospital \\
(4) teraz & now \\
(a) początek choroby & begin of ilness \\
(b) początek pobytu w szpitalu begin of being in hospital \\
(a) koniec choroby & end of ilness \\
(b) koniec pobytu w szpitalu & end of being in hospital \\
\hline
\end{tabular}

Fig. 20. Present, with 2 consecutive states — limited knowledge possibility 
Scheme 11

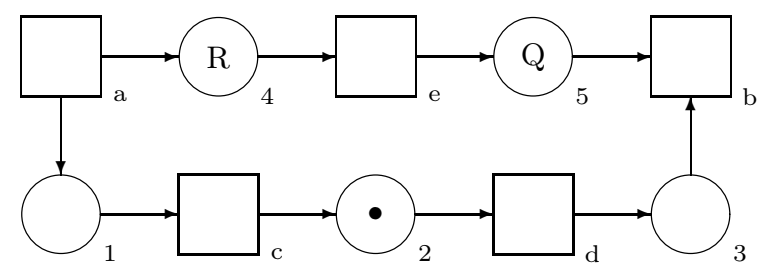

(Bul) Ако той сега е вгв влака, утре ще бгде вгв Варшава; ако сега е вгв Варшава, вчера е трлбвало да бгде вгв влака

(Eng) If he is in a train now, he will be in Warsaw tomorrow; if now he is in Warsaw, he had to be in a train yesterday

(Pol) Jeśli jest teraz $w$ pociagu, jutro będzie w Warszawie; jeśli jest teraz w Warszawie, wczoraj musiał być w pociagu

(Rus) Если сейчас он в поезде, то завтра будет в Варшаве; если сейчас он в Варшаве, то вчера он должен был быть в поезде

\begin{tabular}{|lll|}
\hline (2) Teraz & Now \\
(4) & W pociągu & In a train \\
(5) & W Warszawie & In Warsaw \\
\hline
\end{tabular}

Fig. 21. deterministic, no braching at states 


\section{Scheme 12}

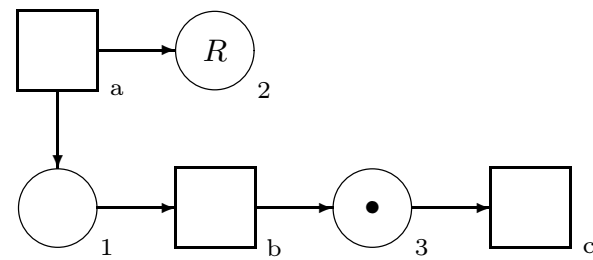

(Bul) Вгзможно е да е все още в отпуска (Eng) Maybe he is still on holidays

(Pol) Możliwe, ze on jeszcze jest na wakacjach

(Rus) Возможно, что он еще в отпуске

(2) Jest na wakacjach he is on holidays now

(3) Teraz Now

(a) Początek wakacji beginning of holidays

Fig. 22. Possible present, known past 
Scheme 13

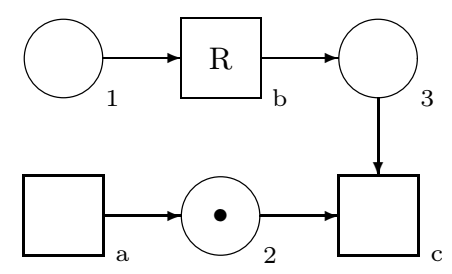

(Bul) Вгзможно е, че неговата отпуска е свгршила (Eng) Possibly he has finished his holidays by now (Pol) Możliwe, że skończył już swój urlop

(Rus) Возможно, что отпуск его уже закончился

(1) Jest na wakacjach he is on holidays

\begin{tabular}{ll} 
(2) Teraz & Now \\
(b) Koniec urlopu & End of holidays \\
\hline
\end{tabular}

Fig. 23. Possible event — indeterministic possibility 


\section{Scheme 14}

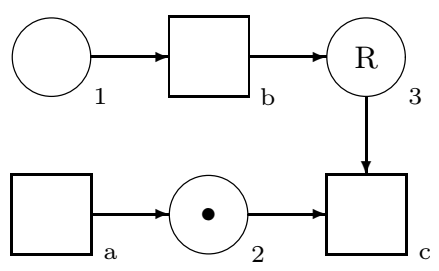

(Bul) Вбзможно е, той да е вече след отпуската си (Eng) Possibly he is out of holidays now

(Pol) Możliwe, że jest on już po urlopie

(Rus) Возможно, что он уже после отпуска

(1) Jest na wakacjach he is on holidays

(2) Teraz Now

(3) Po urlopie Out of holidays

Fig. 24. Present, possible past 


\section{Scheme 15}

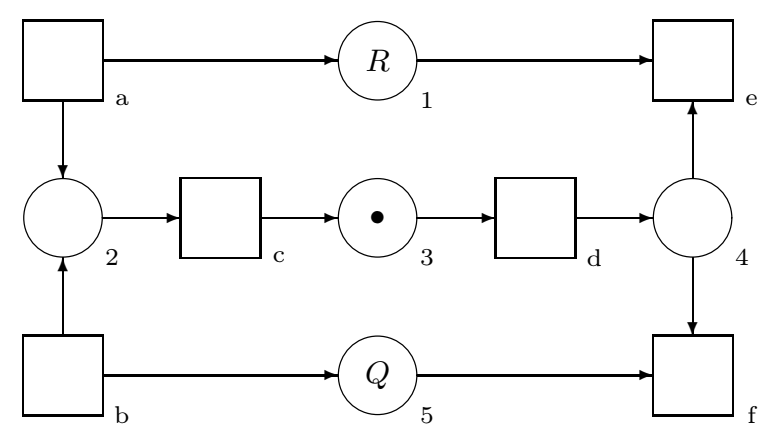

(Bul) Сега Мария е или в Краков, или в Гданск (Eng) Now, Mary is either in Cracow or in Gdansk (Pol) Teraz Maria jest albo w Krakowie, albo w Gdańsku (Rus) Сейчас Мария или в Кракове, или в Гданске

\begin{tabular}{|ll|}
\hline (1) Maria jest w Krakowie & Mary is in Cracow \\
(3) Teraz & Now \\
(5) Maria jest w Gdańsku & Mary is in Gdansk \\
(a) Początek pobytu w Krakowie Beginning of stay in Cracow \\
(b) Początek pobytu w Gdańsku & Beginning of stay in Gdansk \\
(e) Koniec pobytu w Krakowie & End of stay in Cracow \\
(f) Koniec pobytu w Gdańsku & End of stay in Gdansk \\
\hline
\end{tabular}

Fig. 25. Indeterministic mutual exclusion-different termination of states — branching at states 


\section{Scheme 16}

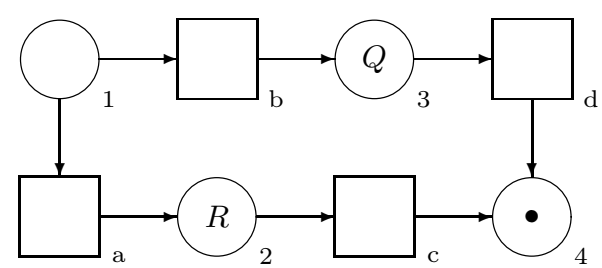

(Bul) Ако той беше казал истината, тя не е била там

(Eng) If he told the truth, she wasn't there

(Pol) Jeśli on mówit prawdę, to jej tam nie było

(Rus) Если он говорил правду, то ее там не было

Another version:

(Bul) Ако тя е била там, той лгже

(Eng) If she was there, he is lying

(Pol) Jeśli ona tam była, on kłamie

(Rus) Если она там была, то он лжет

(2) On mówi prawdę he is telling the truth

(3) Ona tam jest She is over there

(c) Powiedział prawdę He told the truth

Fig. 26. Conditional past 


\section{Scheme 17}

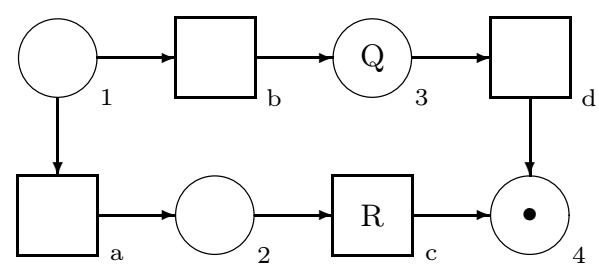

(Bul) Ако той е казал истината, тя не е била там (Eng) If he told the truth, she wasn't there

(Pol) Jeśli on powiedział prawde, to jej tam nie było

(Rus) Если он сказал правду, то ее там не было

Alternatively:

(Bul) Ако тл е била там, той е излггал

(Eng) If she is there, he lyied

(Pol) Jeśli ona tam była, on sktamat

(Rus) Если она там была, он солгал

(2) On mówi prawdę he is telling the truth

(3) Ona tam jest She is over there

(c) Powiedział prawdę He told the truth

Fig. 27. Conditional event 


\section{Scheme 18}

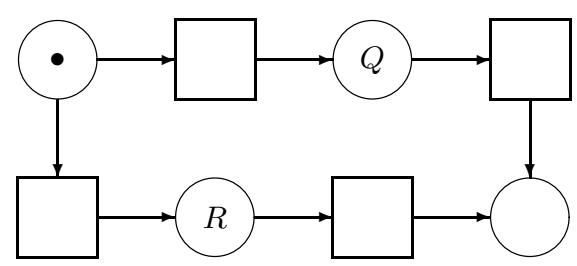

Surely, it will be either $R$ or $Q$

Fig. 28. Future possibility, 1

Scheme 19

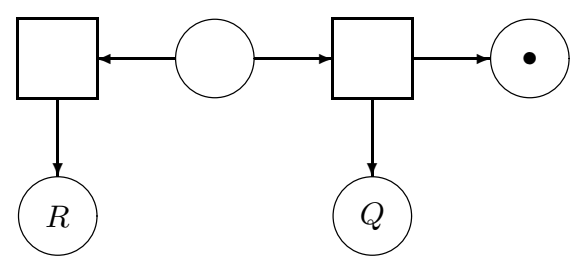

It could be $R$, but $Q$ is; $Q$ is, but it could be $R$ Now you are well $(Q)$, but you could be dead $(R)$

Fig. 29. Future possibility, 2 
Scheme 20

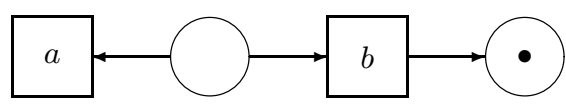

It could happen $a$, but $b$ has happened I could hit you $(a)$, but I didn't do that $(b)$

Fig. 30. Past possibility

Scheme 21

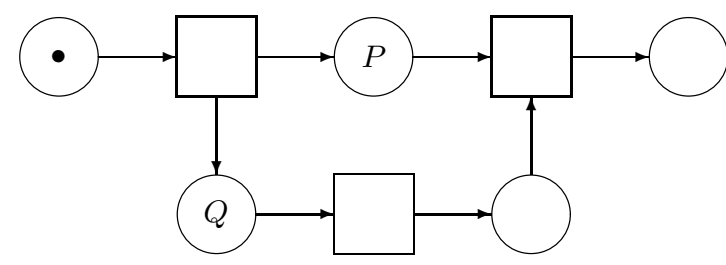

$Q$ will be terminated by Friday $(P)$

Fig. 31. Positive future 
Scheme 22

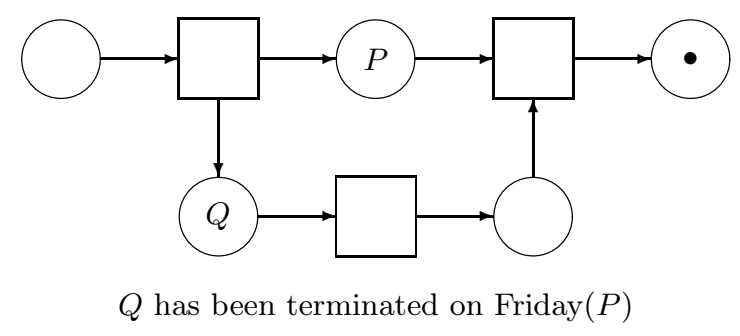

Fig. 32. Positive present 
Scheme 23

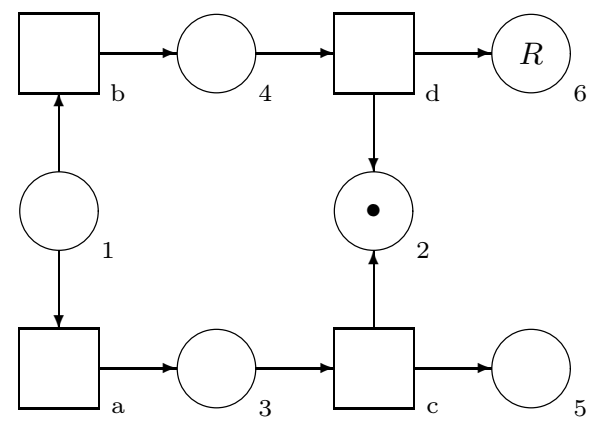

(Bul) Aко беше вчера позвгнила, щях днес да дойда (Eng) If you called me yesterday, I would come today (Pol) Gdybyś wczoraj zadzwoniła, to bym dzisiaj przyszedt

(Rus) Если бы ты вчера позвонила, то я бы сегодня пришел

\begin{tabular}{|ll|}
\hline (1) Wczorajsza decyzja Yesterday's decision \\
(2) Teraz & Now \\
(3) Dzwoni & She is calling \\
(4) Nie dzwoni & She is not calling \\
(5) Przychodzę & I am coming \\
(6) Nie przychodzę & I am not coming \\
\hline
\end{tabular}

Fig. 33. Conditional possibility in the past 
Scheme 24

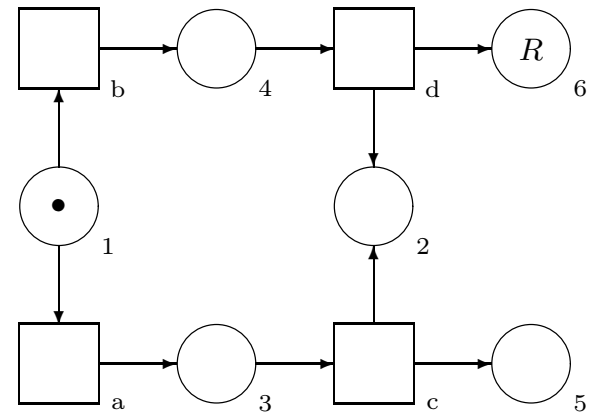

(Bul) Ако ми се обадиш, утре ще дойда (Eng) If you call me, I will come tomorrow (Pol) Jeśli zadzwonisz, to jutro przyjde

(Rus) Если ты позвонишь, завтра я приду

\begin{tabular}{|ll|}
\hline (1) Dzisiejsza decyzja Today's decision \\
(2) Jutro & Tomorrow \\
(3) Dzwoni & She is calling \\
(4) Nie dzwoni & She is not calling \\
(5) Przychodzę & I am coming \\
(6) Nie przychodzę & I am not coming \\
\hline
\end{tabular}

Fig. 34. Conditional possibility in the future 
Scheme 25

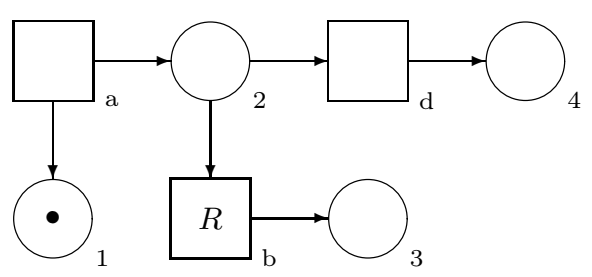

(Bul) Можеш да го убиеш, бе, човек!

(Eng) You can kill him, man!

(Pol) Możesz go zabić, człowieku!)

(Rus) Можешь его убить!

(4) he is alive

(3) he is dead

Fig. 35. 
Scheme 26

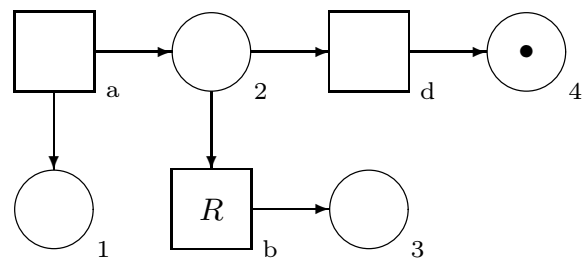

(Bul) Щеше да го убиеш, бе човек! (Eng) You nearly killed him, man! (Pol) O mało go nie zabiłeś, człowieku! (Rus) Тъ мог его убить! (RU)

(4) He is alive (3) He is dead

Fig. 36. Possibility not realized in the past 
Table 4. List of situations with uncertainty caused by a local view

\begin{tabular}{|c|c|c|}
\hline Scheme & Situation & Temporal meaning \\
\hline Scheme 1 & & Present \\
\hline Scheme 2 & & Present, with two independent states \\
\hline Scheme 3 & & Present, with two consecutive states \\
\hline Scheme 4 & & Certainly past, possibly present \\
\hline Scheme 5 & & Event that possibly has already happened \\
\hline Scheme 6 & & Possibly past, certainly present \\
\hline
\end{tabular}


Table 5. List of situations with structural possibilities

\begin{tabular}{|c|c||c|}
\hline Scheme & Situation & Temporal meaning \\
\hline Scheme 7 & & \\
\hline Scheme 10 & & \\
\hline Scheme 14 & & \\
\hline
\end{tabular}


Table 6. List of possibilities induced by a choice

\begin{tabular}{|c|c||c|}
\hline Scheme & Situation & Temporal meaning \\
\hline Scheme 11 & Conditional possibility \\
in the past
\end{tabular}




\section{Conclusions}

In natural languages the semantic category of time, presented in this paper, is formed by a combination of states and events connected with arrows representing the time flow,together with states of utterance supplemented, if necessary, with some additional indications making clear the intention of the speaker. While the past and present tenses serve to inform the reader/leastener about events that took place already and the speaker is sure about their truth or falsehood, the future tense does not supply us with such knowledge. In effect the nets described in the present paper, mainly describing future tense and its relationship to past and present, together with the phenomena of indeterminism, are different than those described in previous papers.

Due to the net formalism one can easily and simply describe all that happens during the state of utterance and after it. The net description makes clear that not only the precedence - succession relation is fundamental for expression the time in natural languages, but also the simultaneity and concurrency relations are equally important and play an important part in understanding natural language sentences.

Our knowledge is changing and increasing; this process is accompanied with changing the relation of the speaker to the described reality. Before Copernicus the statement "the Earth goes round the sun" was false, but nowadays it is true. The form of future tense expresses the laws of the nature, but is it really a "future tense"?

The meaning of the form of futurum in sentences like (1) Sun will set at $5 \mathrm{pm}$ has not the same meaning as in the sentence (2) John will be at home tomorrow. The meaning of (1) one can call the universal - general, since the sun in this season always sets at $5 \mathrm{pm}$, and apparently is related to the general meaning of praesens, see (Косеска, Гаргов 1990). Natural language sentences that describe laws of nature can be viewed as unquestionably true. However, from the natural language point of view, the futurum form has not the meaning of future tense. The cause of future states and events occurring after the utterance state exists prior to the utterance state, at the utterance state, and after it. Therefore, the meaning of such sentences does not depend on the utterance state and can be considered as timeless and universal. Using forms of futurum has nothing to do with the future tense.

In natural languages, difference between past and future arises from the relation earlier - later on one hand, and from the position of the state of utterance with respect to described situation on the other hand. The net description shows clearly the states and events following the utterance state and, at the same time, which of them will occur in effect of a choice between two or more possible events. Such a choice is necessary for the proper understanding the speaker intensions and it has to be consistent with the amount of knowledge of the speaking subject (see schemes 5 and 6 ).

It is worthwhile to note the descrition of conditional sentences. In the present paper, for the sake of clarity and precision we use syntactic means in the form of compound statements with subordinate clauses and construction 'if ... then ...' 
(schemes 2,8,9). The special attention should be paid to the net description given in scheme 15. Bulgarian form of positive perfective futurum praeteriti (futurum exactum praeteriti) of perfective verbs ' where there is lack of other forms expressing conditionality. With similar situation we have in English, where the 'would' form serves to express conditionality. In Pol-

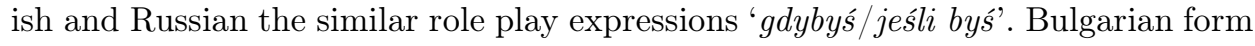
' щяx $\partial а$ дойда' explicitly expresses that the referred event did not happened. The meaning of Bulgarian futurum praeteriti is stressing the lack of a state (an event) after the utterance state. The nets, respecting non-linearity of succession, turn out to be a handy tool for describing such situations.

In scheme 9 a net without actual possibility is presented; more precisely, it describes a past possibility which had been resolved in one way: 'If you stay closer, you will not be alive now'. It shows that discussing hypothetic and unreality in the framework of conditionality has been not justified on semantic level. Each potential sentence is hypothetical, but not the other way round. This observation leads to a restriction of the conditionality notion in natural languages. It is especially significant for the conditionality theory, justified in details in the Bulgarian-Polish Grammar volume, dedicated to the conditional modality in Bulgarian and Polish.

\section{References}

Косеска-Тошева, В., Гаргов, Г. (1990). Семантичната категория определеност/неопределеност, Бблгарско-полска сбпоставителна граматика, том 2 , София.

Koseska-Toszewa, V. (2007). Gramatyka konfrontatywna bułgarsko-polska. vol. 7. Semantyczna kategoria czasu, Slawistyczny Ośrodek Wydawniczy, Warszawa.

Koseska-Toszewa V., Maldzieva, V., Penčev, J. (1996). Gramatyka konfrontatywna bułgarsko-polska, vol.6, part.1, Modalnośc. Teoretyczne problemy opisu. Warszawa.

Koseska V., Mazurkiewicz A. (1988). Net representation of sentences in natural languages, In Advances in Petri Nets, LNCS 340, Springer Verlag, pages 249259.

Koseska V., Mazurkiewicz A. (2009). Net Net Based Description of Modality in Natural Language (on the Example of Conditional Modality), In Proc. of the MONDILEX Second Open Workshop, Kiev.

Mazurkiewicz, A. (2008). A Formal Description of Temporality (Petri Net approach), Lexicographic tools and techniques, In Proc. of the MONDILEX First Open Workshop, Moscow, ISBN 978-5-990813, pages 98-108.

Petri, C. A. (1962). Fundamentals of the Theory of Asynchronous Information Flow, In Proc. of IFIP'62 Congress, North Holland Publ. Comp., pages 386-390.

Reichenbach, H. (1944). Elements of Symbolic Logic, New York, McMillan Publ. Reisig, W. (1985). Petri Nets - An Introduction, New York, Springer Verlag. 
